IZA DP No. 9347

Risk Attitudes and Migration

Mehtap Akgüç

Xingfei Liu

Massimiliano Tani

Klaus F. Zimmermann

September 2015 


\title{
Risk Attitudes and Migration
}

\author{
Mehtap Akgüç \\ CEPS and IZA \\ Xingfei Liu \\ Ryerson University and IZA \\ Massimiliano Tani \\ University of New South Wales and IZA \\ Klaus F. Zimmermann \\ IZA and Bonn University
}

\section{Discussion Paper No. 9347 \\ September 2015}

\author{
IZA \\ P.O. Box 7240 \\ 53072 Bonn \\ Germany \\ Phone: +49-228-3894-0 \\ Fax: +49-228-3894-180 \\ E-mail: iza@iza.org
}

\begin{abstract}
Any opinions expressed here are those of the author(s) and not those of IZA. Research published in this series may include views on policy, but the institute itself takes no institutional policy positions. The IZA research network is committed to the IZA Guiding Principles of Research Integrity.

The Institute for the Study of Labor (IZA) in Bonn is a local and virtual international research center and a place of communication between science, politics and business. IZA is an independent nonprofit organization supported by Deutsche Post Foundation. The center is associated with the University of Bonn and offers a stimulating research environment through its international network, workshops and conferences, data service, project support, research visits and doctoral program. IZA engages in (i) original and internationally competitive research in all fields of labor economics, (ii) development of policy concepts, and (iii) dissemination of research results and concepts to the interested public.
\end{abstract}

IZA Discussion Papers often represent preliminary work and are circulated to encourage discussion. Citation of such a paper should account for its provisional character. A revised version may be available directly from the author. 
IZA Discussion Paper No. 9347

September 2015

\section{ABSTRACT}

\section{Risk Attitudes and Migration*}

To contribute to a scarce literature, in particular for developing and emerging economies, we study the nature of measured risk attitudes and their consequences for migration. We also investigate whether substantial changes in the risk environment influences risk tolerance. Using the 2009 RUMiC data for China, we find that rural-urban migrants and their family members are substantially less risk-averse than stayers. We further provide evidence that individual risk attitudes are unaffected by substantial changes in the environment and that risk tolerance is correlated across generations.

JEL Classification: J61, D81

Keywords: risk aversion, risk attitudes, migration, China

Corresponding author:

Massimiliano Tani

Institute for the Study of Labor (IZA)

Schaumburg-Lippe-Strasse 5-9

53113 Bonn

Germany

E-mail: Tani@iza.org

\footnotetext{
* The Longitudinal Survey on Rural Urban Migration in China (RUMiC) consists of three components: the Urban Household Survey, the Rural Household Survey and Migrant Household Survey. It was initiated by a group of researchers at the Australian National University, the University of Queensland and the Beijing Normal University. The survey has been supported by the Chinese Foundation of Social Sciences and the Institute for the Study of Labor (IZA), which also developed and provides the Scientific Use Files (see Akgüç et al., 2014a). We are grateful to the responsible editor of this paper, Corrado Giulietti, three anonymous referees and to participants at the session "Remittances, Job Search and Risk Attitudes in China" of the $10^{\text {th }}$ IZA/World Bank Conference on Employment and Development on June 4, 2015 in Bonn for valuable useful comments on previous drafts, and to Victoria Finn for editorial suggestions.
} 


\section{Introduction}

There is little doubt that economic migration contributes to "grease for the wheel of the labor market" (Borjas, 2001), implying that it plays a pivotal role in reallocating labor resources across countries and regions with, generally, improvements in productivity. There is also little doubt that understanding why individuals decide to migrate helps the design of effective migration and labor market policies, especially where migration is a new phenomenon.

Typically economists frame the decision to migrate as a comparison of uncertain costs and benefits of moving. Indeed, migration is a risky endeavor. Migrants have less information about opportunities and conditions in the destination labor market as well as opportunities to consume and use leisure time relative to the natives. Even after migrating they continue to face uncertainty not shared by locals, such as anti-immigration sentiments and discrimination from the native population, the possibility of being deported if migration is undocumented, or be unable to help family left behind at some critical times (e.g. sudden death of a family member). Given the additional uncertainty involved, and assuming rationality, one would expect migrants to be highly tolerant of risk for a given expected gain.

To date, there is only limited empirical evidence verifying this hypothesis, and such evidence is gathered from either laboratory experiments or data predominantly collected in high income countries with established institutions (Bonin et al., 2009 and 2012; Jaeger et al., 2010; Dohmen et al., 2011 and 2012; Williams and Baláž, 2014). Evidence from countries undergoing rapid economic and social transformations is minimal (Gibson and McKenzie, 2009; Hao et al., 2014; Dohmen et al., 2015). Yet it is precisely from economies in transitions that new insights on the link between risk and migration can emerge, as in such places people experience at once a wider set of choices about where to work and live and profound changes in the risk environment in which they take decisions. This paper focuses on the largest economy in transition, China, to study whether more risk-tolerant individuals in rural areas are more likely to migrate.

China is unique in that it has experienced the largest volume of internal migration (Zhao, 2005) but it operates an inflexible residence status system ("hukou"), which defines where individuals have rights to access local public goods. Residence was effectively fixed in the late 1950s and changes were permitted only in limited circumstances. Although one may not be able to change his or her residence status, internal migration in China is unrestricted. An individual with residence in A can move to B within the same or another province, but at the 
cost of losing access to local public goods at subsidized prices. This means that migrants have no access to subsidized housing, healthcare, unemployment insurance or pension in the cities where they moved to. Perhaps more critical in today's China is that children often cannot acquire a place in school close to where their migrant parent(s) live; hence migrants' children may have to remain in the hometown, where left-behind family members look after them.

Given the restrictions imposed by the hukou system, are rural-urban migrants less risk-averse than stayers? Are they coming from less risk-averse households? Do they migrate as a result of their tolerance for risk or does migrating change their level of risk-aversion? We are able to answer these questions by using the rural sample of the Survey on Rural Urban Migration in China (RUMiC; see Akgüç et al., 2014a). This dataset has rich information about demographic, socio-economic and psychological characteristics of household members, including questions on risk aversion. We find that an individual's risk tolerance positively contributes to the decision to migrate, and this result is robust to several specifications. We also find evidence that causality runs from risk tolerance to migration, and that risk tolerance correlates across generations.

The remainder of the paper is organized as follows: Section 2 provides a short summary of the literature on risk and migration. Section 3 describes the data and Section 4 discusses the methodology. Section 5 presents the results. Section 6 discusses the robustness of the results. Section 7 concludes.

\section{Literature}

The traditional economic approach to migration is to view it as the result of an individual optimization decision comparing the present value of its benefits and costs (Sjaastad, 1962). Early models do not consider individual differences in risk tolerance, and introduce uncertainty as a disturbance affecting everyone in the same way. Perhaps the best-known example is when finding employment is subject to a probability (Todaro, 1969; Harris and Todaro, 1970), which leads would-be migrants to compare expected rather than certain benefits and costs of migration, and self-select into moving or staying (Borjas, 1987) or deciding for how long to migrate (Dustmann, 1997).

Lack of empirical support that rural-urban migration occurs as a result of differences in expected incomes resulted in the formulation of new hypotheses about risk and migration, 
though still within the theoretical underpinning of expected utility maximization and no individual heterogeneity in risk aversion. Work in this literature has put forward the idea that risk tolerance amongst migrants may differ 'structurally' from that of natives. This could occur because migrants may simply be more risk-loving than natives (Sahota 1968). Bonin et al. (2009) found the reverse suggesting that selectivity issues and general ethnic differences in risk attitudes may be possible at work: If the receiving country is a welfare state, it may receive more of the risk-averse migrants. Or the more risk-loving migrants may move onward or return home. An alternative explanation could be that the attracted migrants are from source countries with more risk averse populations. A key question is then whether migrants are more or less risk tolerant than the populations they come from.

Alternatively, the decisions of migrants may be affected by bounded rationality, which limits their ability to undertake several decisions at once, especially when information is incomplete (Simon 1983). Migration may also occur when individuals trade-off risk inter-temporally, preferring immediate higher risks for subsequent lower risks, or when capital markets are imperfect (Katz and Stark 1986; Stark, 1981). Migration can also arise as the result of a household's, rather than an individual's, optimization to diversify earning risk amongst its members (Stark and Levhari 1982; Rosenzweig, 1988; Stark and Lucas, 1988; Rosenzweig and Stark, 1989; Jalan and Ravallion, 2001; Chen et al., 2003).

The idea that individuals differ in risk tolerance is at the core of the theory of choice under uncertainty and the development of operational measures of risk aversion (Arrow, 1965; Pratt, 1964). The underlying hypothesis is that the attitude an individual has towards risk determines relevant outcomes in a variety of contexts like career decisions or the choice of a portfolio of risky investments. There is some evidence supporting that risk aversion is individual-specific (Williams and Baláž, 2014; Guiso and Paiella, 2006). Models developed outside the expected utility theory also support this hypothesis and provide additional empirical support (Czaika, 2012).

Existing work has established some of the main determinants of risk aversion, purporting that risk tolerance is a stable trait that is inherited rather than a momentary behavior. For instance, through an experimentally validated survey in Germany, Dohmen et al. (2011 and 2012) show that one's willingness to take risk is a function of gender, age, height, and parental background. They also find that simply asking people for a general self-assessment of their willingness to take risks in fact generates a useful all-around measure of risk tolerance. When facing uncertainty, this measure captures a more comprehensive concept of an individual's risk attitude compared to strict measures of risk tolerance towards a particular action or 
scenario. Therefore this self-reported information is viewed as more relevant when looking at broad decisions such as migration, as migration triggers multiple dimensions of uncertainty. Dohmen et al. (2012) also find that risk attitudes are fairly stable across different contexts, implying that the individuals tend to display stable risk tolerance even when the risk landscape in which they live changes dramatically. Furthermore, there is evidence of positive assortative mating regarding risk attitudes, and that risk tolerance is transmitted intergenerationally from parents to children (Bonin et al, 2009; Dohmen et al., 2012;).

Notwithstanding the literature viewing migration as a risky decision, empirical evidence of the relationship between the migration decision and migrating individual's risk tolerance isscarce, especially in the case of economies in transition (Heitmuller, 2005; Conroy, 2009: Gibson and McKenzie, 2009; Hao et al., 2014). Jaeger et al. (2010) find that risk tolerance and migration in Germany are positively related. More risk-loving individuals are more likely to migrate after controlling for conventional migration determinants such as age, family background, and geographical measures. They argue that, at least for the German internal migration case, "general uncertainty about other locations is an important channel through which risk attitudes determine intra-German geographic mobility and that the average mover is relatively more willing to take risks." Using the same German survey data, but focusing on international migrants in Germany, Bonin et al. (2009) find that first generation immigrants are more risk averse than their native counterparts, while second-generation immigrants exhibit higher risk preferences similar to natives. Bonin et al. (2012) find that in this adjustment process ethnic persistence preserves the immigrant-native gap in risk proclivity, while assimilation closes it.

We extend the migration and risk tolerance analysis to the most important economy in transition, China, using survey data (Hao et al, 2014, use experimental data) ${ }^{1}$. In particular we study the effect of risk tolerance and other determinants on the probability to migrate paying particular attention to the direction of causality. As part of the robustness tests carried out, we also document whether migrants come from more risk-loving families.

\footnotetext{
${ }^{1}$ Dustmann et al. (2015) also study the link between risk tolerance and migration in China. Although this study is not yet available in the public domain, the analysis focuses on the link between an individual's probability of migrating of the distribution of risk tolerance amongst family members. We became aware of this paper after a hardcopy was available at the 17th IZA/CEPR European Summer Symposium in Labor Economics on September 9, 2015.
} 


\section{Data}

Our analysis is based on data extracted from the Rural Household Survey, or RHS, of the RUMiC database (Akgüç et al., 2014a). Although the RHS public file has to date published data covering 2008 and 2009, we use only the 2009 cross-sectional information as no question on risk attitude was asked in 2008. The RHS covers 51,136xy individuals from around 8,000 households in rural areas. It includes comprehensive and rich information on household and personal characteristics. To identify a migrant, we restrict our focus to rural hukou holders and use the responses to whether or nor the individual surveyed has ever migrated for work in the past. The identifying answer for having done so includes respondents who migrated from their rural villages to take up employment of various durations. We do not differentiate between those migrating for shorter or longer periods of time, as the majority of internal migration in China is temporary.

The subjective measure of risk comes from a general risk attitude question, which asks all household members aged 16 and above who are present at the interview:

"Generally, some people prefer to take risk, and others try to avoid any risk. If it is to rank the risk from low to high as 0 to 10 (as shown by the following chart), 0 is "never take risk," 10 is "like to take risk," which level do you belong to? (choose a number from 0 to 10$)$."

This question closely follows the risk attitude measure provided by the German Socioeconomic Panel (GSOEP), and used among others such as Bonin et al. (2009) and Jaeger et al. (2010). The ULMS has made a comparable variable available (see Lehmann et al., 2012), which Dohmen et al. (2015) have studied. This measure has been proven to serve as a good measure of general risk tolerance (Dohmen et al, 2011; Jaeger et al., 2010; Frijters, et al. 2011).

Table 1 summarizes the main variables used in the analysis. Among the 5,475 rural households in our final sample, about $69 \%$ have sent migrants out of village to work. The sample contains 8,638 individuals from rural households (1,670 movers and 6,968 stayers), among which 19\% had migrated for work sometime before the survey was conducted. Relative to rural stayers, on average migrant workers are younger (43 vs. 51 years of age) and more likely to be male ( $71 \%$ vs. $51 \%)$. Migrant workers are more likely to have completed junior middle school relative to comparable stayers (76\% vs. $64 \%$ ). They are also more likely to be the household head (57\% vs. 49\%). The migrant household head's spouse is less likely 
to have ever migrated for work (19\% vs. $42 \%)$. With respect to risk tolerance, the unconditional mean of the self-assessed risk level is significantly higher among migrants (3.19 out of 10) than stayers (2.33) - .this is a whopping difference of about $37 \%$.

\section{Empirical strategy}

To analyze the relationship between risk tolerance and migration, we estimate a microeconometric model of the decision to migrate augmented by the variable measuring risk tolerance. This approach follows Jaeger et al. (2010) and relies on the finding that risk tolerance is a stable trait found by Dohmen et al. (2012 and 2015). In particular, we estimate the probit specification:

$$
\operatorname{Pr}\left(M_{i}=1\right)=\alpha_{0}+Z_{1} \alpha_{1}+Z_{2} \alpha_{2}+\alpha_{3} * \text { Risk }_{i}+v_{i}
$$

where $M$ represents the decision to migrate (a dummy variable); $Z_{1}$ is a vector of individual characteristics that includes age, age squared, marital status, gender, educational level, weight, and height; $Z_{2}$ is a vector of household characteristics, which includes the number of children, number of siblings, the average age in the household, its size, the average land size owned by the household at the time of the survey, and the household income level. The parameter of interest in equation (1) is $\alpha_{3}$ since that captures the effect of risk tolerance on the migration decision. We estimate model (1) for the household head and repeat the same analysis for spouses in order to document this relationship among other household members.

We then consider the possibility that the migration decision may affect self-assessed risk tolerance (reverse causality). Unfortunately, we cannot apply the technique suggested by Jaeger et al. (2010) consisting in regressing the change in risk tolerance between two different points in time on a dummy variable that equals one if the individual migrated during the period because we only have cross-sectional data. However, we exploit unique information contained in the RUMiC about a large exogenous shock to an individual's risk environment, namely whether an individual has changed his or her hukou status due to expropriation, to verify the stability of self-assessed risk tolerance as a robustness test. Gaining urban hukou status in any Chinese city $i$ grants access to that city's range of social benefits and services, and to a more uniform labor market with no barriers to enter secure jobs in state-owned enterprises. We claim that expropriation with hukou change can be seen as a positive exogenous shock as China's residence status did not allow locational choice: people had no choice but to reside where they were originally registered in the late 1950s (whilst expropriations with changes in hukou recorded by RUMiC occur much later). 
The empirical strategy used to verify the stability of self-assessed risk is based on the linear regression model:

$$
\text { Risk }_{i}=\beta_{0}+X_{i} \beta_{1}+\beta_{2} E_{i}+\beta_{3} P_{i}+\varepsilon_{i}
$$

where the dependent variable is individual $i$ 's subjective risk tolerance level and $X$ includes demographic and family background characteristics. $E$ is a dummy variable equal to 1 if the individual has changed hukou due to expropriation ${ }^{2}$ whereas $P$ indicates provincial fixed effects and $\varepsilon$ is an error term. The coefficient of interest in equation (2) is $\beta_{2}$, which is the estimated effect of a large shock following a hukou change on risk tolerance. Estimates are performed by OLS using robust standard errors.

Finally, following Dohmen et al. (2012), Bonin et al. (2009), Brown et al. (2015) amongst others, we explore whether there is a link between a parent's risk tolerance and the children's probability to migrate as a further robustness check. To do so we perform the regression:

$$
\text { ChldRisk }_{i}=\gamma_{0}+H_{i} \gamma_{1}+\gamma_{2} * \text { ParRisk }_{i}+\gamma_{3} P_{i}+\eta_{i}
$$

where $H_{i}$ is a vector of personal characteristics that includes age, age squared, education, number of children, marital status, number of siblings, height, and weight, whereas $P_{i}$ is a vector of provincial fixed effects.

\section{Results}

We estimate the effect of self-assessed risk tolerance on the probability to migrate on RUMiC's rural sample data using equation (1) with robust standard errors and province fixed effects. The marginal effects are reported in Table 2. The first row shows that risk tolerance positively affects the decision to migrate, in line with Jaeger et al. (2010), Bonin et al. (2009), Gibson and McKenzie (2009), Hao et al. (2014), Williams and Baláž (2014). This result holds for the household as a whole (everyone at home) as well as for household heads and their spouses analyzed separately. ${ }^{3}$ The effect is always statistically significantly different from zero at the $1 \%$ level of significance. Its magnitude is in the order of $1 \%$ for the household

\footnotetext{
${ }^{2}$ The RUMiC includes a question asking whether a respondent's hukou has changed and if so why. Most expropriated households with hukou change (85\%) are drawn from the urban sample, which covers medium- and large-sized cities. The remaining observations are sourced from the rural sample, which covers rural areas as well as small-sized urban centers.

${ }^{3}$ The coefficient in model (1) performed on children aged 16 and above is positive and significant when monthly income (not statistically significant) is omitted from the analysis. When included, the marginal effect of risk tolerance on the migration decision is positive but no longer significant due to the severe reduction in the number of observations where children report their monthly income and the likely presence of high measurement error.
} 
head and $0.5 \%$ for the spouse, which is about as large as that of age or education, though opposite in sign. The last column analyzes the effect for other members of the household, which has received a larger size but only a smaller significance level (5\%) probably because of the much smaller sample size. Although driven only by a few variables, McFadden's Pseudo $\mathrm{R}^{2}$ suggests quite a good fit according to the standards expected (Veall and Zimmermann, 1992).

Besides risk tolerance, the main migration predictor is gender (male). This is in line with Hao et al (2014) and the literature cited in Williams and Baláž (2014), but contrasts with Jaeger et al (2010), in which gender had no statistically significant effect on migration. This difference is not easily explained, though it may reflect the different nature of migration captured in this study (temporary migration, predominantly carried out by males) and in theirs (permanent migration, mostly for work or family reasons). Having siblings has a positive effect on the probability to migrate, especially on the spouse's probability to migrate, since in China siblings commonly take care of the family/household when an individual migrates. Indeed, when model (1) is run separately on sub-groups of observations arranged according to the number of siblings $(0,1$, more than 1$)$, the self-assessed risk measure makes no contribution to the probability to migrate in the case of no siblings while it is positive and statistically significant as the number of siblings grows.

Perhaps more surprising in Table 2 is the extent of characteristics that do not seem to matter in the decision to migrate (this also arises in the incremental regressions reported in Table A2), including physical, demographic, and employment characteristics. With reference to demographics, age does not emerge as a key migration determinant and neither does marital status, unlike in Jaeger et al. (2010), or the number of children. We also do not find any effect from height and weight, against existing evidence that these features matter for labor market outcomes, as they are often considered as signals of good health and productivity (Case and Paxons, 2008). The different results emerged from our analysis perhaps reflect that the decision to migrate that we captured using the RHS includes individuals who do so only temporarily on a seasonal or ad hoc basis, and possibly to not too distant places, while most other studies focus on permanent or long-term migration (Jaeger et al., 2010; Gibson and McKenzie, 2009).

Education beyond mandatory schooling appears to reduce the probability of migration for the household head, though the estimate is statistically no different from zero. The negative sign is possibly a reflection of job sorting in China's rural villages where higher education is likely 
to be uncommon within the local population and thus a fundamental quality to secure positions of responsibility in the community's administration. In contrast, the coefficient for education at junior high school is statistically significant but only in the regression performed on the household as a whole. This result supports that the decision to migrate occurs in a household context rather than just the household head and spouse. It also highlights that migrants are likely to possess more than basic literacy levels, as was also found in Jaeger et al. (2010). The estimate for land tenure holding has the expected negative sign but it is statistically not different from zero, while that of income has a positive sign, supporting that migration is not an activity restricted to the poorest social groups.

\section{Robustness}

Thus far we have highlighted the main determinants of the probability to migrate, as well as the positive contribution to it attributable to the migrant's tolerance for risk. To exclude the possibility that there is reverse causality between migration and risk tolerance, whereby migrating triggers a change in risk preferences, we investigate risk tolerance stability when there is a significant shock to an individual's risk environment. The idea behind this robustness test is that the migration decision is unlikely to influence a stable risk tolerance measure, thus keeping intact the causal interpretation of the results discussed so far. Our robustness test is based on model (2) and exploits a unique quasi-natural experiment that has occurred in China: the change of hukou status from rural to urban hukou due to land expropriation (for details see Akgüç et al., 2014b).

The hukou system was introduced in 1958 as a measure to foster the Big Push industrialization strategy of the regime at that time. To quickly accumulate capital in the newly nationalized manufacturing sector, which was mostly located in cities, the government collectivized the rural population as well as directed the food and raw materials production. It then elected to become the sole and mandatory buyer and seller of rural produce in order to set the prices at which agricultural inputs were sold. The regime also registered each person as rural or urban in 1955; therefore implementing the hukou system three years later, it has prevented rural hukou holders to become urban hukou holders without the prior approval of the destination. These measures capped the annual quota of conversions to about $0.15 \%-0.2 \%$ of the non-agricultural population (Chan, 2009).

Although economic reforms post-1978 have enabled people to relocate from rural to urban areas, the hukou system still prevents a rural hukou holder living in an urban center to enjoy 
the same rights, privileges, and prices as their urban counterparts. Expropriated farmers compensated with rural-urban hukou status change can then access public welfare rights that include, for example, better healthcare facilities and pension rights as well as access to local schools for their children. Since the Chinese population is classified as rural or urban on the basis of residence in 1958, this particular form of expropriation can be viewed as exogenous.

Table 3 shows the unconditional means of risk attitudes by expropriation group. These data are extracted from the 2009 cross-sections of RUMiC's urban, migrant, and rural household surveys. In general, migrants who chose to move have a higher risk tolerance than expropriated individuals gaining urban hukou rights who "move" involuntarily as a result of an administrative decision. The data suggest that the majority of expropriated households received their urban hukou in the early 2000s, specifically 2003 and 2004. As the survey question about subjective risk attitudes was asked in 2009, we only capture the subjective risk level after the treated individuals had been exposed to the "quasi-experiment." To compensate for the lack of a natural counterfactual, we obtain alternative reference groups. Each of these takes the value of zero in the dummy variable $E$ appearing in model (2). These five reference groups differ in changing and non-changing their residence or hukou status, or both. We hence measure the risk tolerance of a change in hukou status following expropriation relative to (i) non-changers of both hukou and residence (urbanites and rural stayers), (ii) changers of both hukou and residence (those obtaining an urban hukou because of their skills), and (iii) hukou non-changers but residence changers (migrants). We then perform separate regressions of model (2) on household heads and their spouses using each of the five reference groups.

Table 4 summarizes the estimates of the several $\beta_{2}$ obtained from performing separate OLS regressions on household members. The coefficients obtained on demographic and labor market controls as well as the provincial fixed effects are not reported, but their signs and significance support the results in the literature. Namely, risk tolerance is higher for males and married household heads, and increases with income. Education positively affects risk tolerance but only when the expropriated are compared to native urban hukou holders, while it is statistically not significant in every other case. Risk tolerance is not affected by age in any of the regressions performed, suggesting a stable nature of risk tolerance over the lifecycle. 
As evidenced in the table, the estimates of $\beta_{2}$ are not statistically different from zero, with only one exception ${ }^{4}$. Given that obtaining the rights to access a city welfare system appears to be a sufficiently large shock to trigger a change in risk tolerance, the lack of an effect for household heads and their spouses across the five reference groups supports the robustness of risk tolerance as a stable measure and its role in determining migration decisions rather than vice-versa. This interpretation complements what has been found in laboratory experiments (Dohmen et al., 2011) and in the field, including in transition economies (Dohmen et al., 2015).

As a final robustness check, we explore whether the link between risk tolerance and migration arises systematically within the household. In other words, we look at whether individuals deciding to migrate not only have a higher tolerance for risk but also if they come from families with an above-average risk tolerance level (shown in Table 5). To do so we apply model (3), which links the household head's risk tolerance to that of his or her parents and children. ${ }^{5}$ The results reported in Table 6 seem to show that parental risk tolerance positively and strongly affects that of their children. Migrants appear to come from families with a higher tolerance for risk. This suggests that this characteristic may also explain differences in outcomes related to migration away from the countryside, such as higher income, consumption, and investment. Children appear to acquire their tolerance for risk from both parents, though slightly more so from their fathers, which aligns with evidence presented amongst others by Dohmen et al. (2012), Bonin et al. (2009), Brown and van del Pol (2015), and Kimball et al. (2009).

\footnotetext{
${ }^{4}$ The only exception is the case of highly skilled migrant household heads, where the effect of expropriation is negative and statistically significant. Nonetheless this result illustrates the high risk tolerance of individuals choosing to migrate to a city to acquire tertiary education and subsequently obtaining a job there by virtue of their newly acquired skills. This group has the highest average risk tolerance, as evidenced in Table 3.

${ }^{5}$ This analysis is to be considered explorative at this stage, as it is performed on a much smaller number of observations relative to the previous one, reflecting that subjective questions are asked only to household members who are present at the interview. However, there seems to be no systematic variation between the means of the observed variables for households where intergenerational information on subjective risk tolerance is available vis-à-vis those missing that information (Table A1). Key observable variables covering demographic, family, human capital and labor market characteristics are similar between households with and without complete information on risk tolerance. Detectable differences only emerge with reference to the regional composition of the place of residence, and especially for the cases of Henan, Chongqing, and Sichuan, for which unfortunately we cannot provide an explanation.
} 


\section{Conclusions}

The origins and consequences of risk attitudes are understudied, in particular in transition and emerging economies. Therefore, this paper investigates an important field using the 2009 RUMiC data for China.

We find strong support that risk proclivity and migration are positively related. This finding aligns with those obtained in more economically developed countries. We also find that rural stayers are substantially more risk-averse than migrants and migrants' family members. Our analysis supports that risk tolerance is correlated within families across generations.

It is often argued that families in rural areas may use out-migration of certain family members to alleviate the effect of unsteady income. In the context of rural-urban Chinese migration, the urban-rural income gap is so high that risk attitude may not serve as a channel to deal with income shocks in rural areas, as had been assumed in early models of income uncertainty and migration. ${ }^{6}$ This is especially true given that migrant workers often face very low unemployment rates in Chinese cities thanks to their job searching through networks and the huge demand for low-skilled labor in the country's urban labor markets. Against the hypothesis of migration as a reaction to mitigate a negative income shock, we find that people with higher risk tolerance embrace migration to take advantage of opportunities and higher expected wages available in the urban labor markets following rapid economic development.

\footnotetext{
${ }^{6}$ According to Sicular et al. (2007), the urban-rural income ratio was 2.38 in 2002 and tended to increase after adjusting for living cost. Meng et al. (2010) also show that earning gaps are quite high between rural and urban labor markets in China.
} 


\begin{tabular}{|c|c|c|c|c|}
\hline \multirow[b]{2}{*}{ Variable name } & \multicolumn{2}{|c|}{ Mover } & \multicolumn{2}{|c|}{ Stayer } \\
\hline & Mean & St.Dev & Mean & St.Dev \\
\hline Risk level & 3.19 & 2.45 & 2.33 & 2.23 \\
\hline Male & 0.71 & 0.45 & 0.51 & 0.50 \\
\hline Age & 42.65 & 9.98 & 50.86 & 10.69 \\
\hline $\mathrm{Age}^{2} / 100$ & 19.19 & 8.85 & 27.01 & 11.22 \\
\hline Elementary or no school & 0.24 & 0.43 & 0.36 & 0.38 \\
\hline Junior middle school & 0.58 & 0.49 & 0.47 & 0.50 \\
\hline Senior middle or above & 0.18 & 0.38 & 0.17 & 0.38 \\
\hline No. of children & 1.74 & 0.92 & 2.18 & 1.07 \\
\hline Married & 0.98 & 0.15 & 0.96 & 0.21 \\
\hline Height (in cm) & 165.68 & 6.65 & 163.94 & 6.80 \\
\hline Weight (in kg) & 62.21 & 8.44 & 60.25 & 8.44 \\
\hline No. of siblings & 3.27 & 2.19 & 3.36 & 1.86 \\
\hline Household head & 0.57 & 0.50 & 0.49 & 0.50 \\
\hline Spouse of the household head & 0.19 & 0.39 & 0.42 & 0.49 \\
\hline Family size & 4.33 & 1.29 & 4.29 & 1.39 \\
\hline Household land (in $\mathrm{Mu}$ ) & 4.21 & 4.20 & 4.29 & 4.78 \\
\hline Household age & 35.90 & 8.18 & 38.49 & 9.27 \\
\hline Household income & 1.76 & 1.68 & 1.81 & 2.03 \\
\hline
\end{tabular}


Table 2 - Risk and migration (marginal effects)

\begin{tabular}{|c|c|c|c|c|}
\hline Decision to move & $\begin{array}{l}\text { Everyone } \\
\text { at home }\end{array}$ & $\begin{array}{c}\text { Household } \\
\text { head }\end{array}$ & Spouse & $\begin{array}{c}\text { Other } \\
\text { members }\end{array}$ \\
\hline Risk attitude & $\begin{array}{c}0.009 * * * \\
(0.002)\end{array}$ & $\begin{array}{c}0.009 * * * \\
(0.003)\end{array}$ & $\begin{array}{c}0.005 * * * \\
(0.002)\end{array}$ & $\begin{array}{l}0.019^{* *} \\
(.008)\end{array}$ \\
\hline Male & $\begin{array}{c}0.153 * * * \\
(0.009)\end{array}$ & $\begin{array}{c}0.127 * * * \\
(0.019)\end{array}$ & $\begin{array}{l}0.158 * * * \\
(0.044)\end{array}$ & $\begin{array}{c}0.152 * * * \\
(0.039)\end{array}$ \\
\hline Age & $\begin{array}{c}-0.013 * * * \\
(0.003)\end{array}$ & $\begin{array}{l}-0.002 \\
(0.007)\end{array}$ & $\begin{array}{l}-0.008 \\
(0.005)\end{array}$ & $\begin{array}{c}0.002 \\
(0.013)\end{array}$ \\
\hline $\mathrm{Age}^{2} / 100$ & $\begin{array}{c}0.001 \\
(0.003)\end{array}$ & $\begin{array}{l}-0.009 \\
(0.006)\end{array}$ & $\begin{array}{c}0.000 \\
(0.006)\end{array}$ & $\begin{array}{l}-0.020 \\
(0.144)\end{array}$ \\
\hline Junior middle school & $\begin{array}{c}0.017 * * \\
(0.010)\end{array}$ & $\begin{array}{c}0.009 \\
(0.015)\end{array}$ & $\begin{array}{c}0.009 \\
(0.010)\end{array}$ & $\begin{array}{l}-0.005 \\
(0.053)\end{array}$ \\
\hline Senior middle school + & $\begin{array}{l}-0.018 \\
(0.013)\end{array}$ & $\begin{array}{l}-0.0234 \\
(0.019)\end{array}$ & $\begin{array}{c}0.020 \\
(0.018)\end{array}$ & $\begin{array}{c}-0.148 * * * \\
(0 .-52)\end{array}$ \\
\hline No. of children & $\begin{array}{l}-0.009 \\
(0.006)\end{array}$ & $\begin{array}{l}-0.010 \\
(0.008)\end{array}$ & $\begin{array}{c}-0.004 \\
(0.007)\end{array}$ & $\begin{array}{l}-0.032 \\
(0.026)\end{array}$ \\
\hline Marital status & $\begin{array}{c}0.015 \\
(0.025)\end{array}$ & $\begin{array}{r}0.032 \\
(0.035)\end{array}$ & omitted & $\begin{array}{r}0.076 \\
(0.075)\end{array}$ \\
\hline Household size & $\begin{array}{c}0.009 * * \\
(0.004)\end{array}$ & $\begin{array}{l}-0.001 \\
(0.006)\end{array}$ & $\begin{array}{c}0.000 \\
(0.004)\end{array}$ & $\begin{array}{c}0.000 \\
(.0 .020)\end{array}$ \\
\hline Land size & $\begin{array}{c}0.000 \\
(0.001)\end{array}$ & $\begin{array}{l}-0.001 \\
(0.002)\end{array}$ & $\begin{array}{c}0.001 \\
(0.001)\end{array}$ & $\begin{array}{c}-0.002 \\
(.0 .005)\end{array}$ \\
\hline No. siblings & $\begin{array}{c}0.006^{* * *} \\
(0.002)\end{array}$ & $\begin{array}{c}0.005 \\
(0.003)\end{array}$ & $\begin{array}{c}0.005^{* *} \\
(0.002)\end{array}$ & $\begin{array}{l}0.033 * * \\
(.0 .015)\end{array}$ \\
\hline Height (in cm) & $\begin{array}{c}0.000 \\
(0.001)\end{array}$ & $\begin{array}{c}0.000 \\
(0.001)\end{array}$ & $\begin{array}{c}0.001 \\
(0.001)\end{array}$ & $\begin{array}{l}-0.003 \\
(0.003)\end{array}$ \\
\hline Weight (in kg) & $\begin{array}{c}0.001 \\
(0.001)\end{array}$ & $\begin{array}{c}0.000 \\
(0.001)\end{array}$ & $\begin{array}{c}0.000 \\
(0.001)\end{array}$ & $\begin{array}{c}0.008^{* * *} * \\
(0.003)\end{array}$ \\
\hline Household mean age & $\begin{array}{c}0.003 * * * \\
(0.001)\end{array}$ & $\begin{array}{c}0.000 \\
(0.001)\end{array}$ & $\begin{array}{c}0.002 * * \\
(0.001)\end{array}$ & $\begin{array}{c}0.004 \\
(0.003\end{array}$ \\
\hline Household income & $\begin{array}{c}0.001 \\
(0.003)\end{array}$ & $\begin{array}{c}0.002 \\
(0.003)\end{array}$ & $\begin{array}{c}-0.001 \\
(0.003)\end{array}$ & $\begin{array}{l}-0.003 \\
(0.010)\end{array}$ \\
\hline Province fixed effects & YES & YES & YES & YES \\
\hline $\begin{array}{l}\text { Observations } \\
\text { McFadden's Pseudo R }{ }^{2}\end{array}$ & $\begin{array}{l}8,638 \\
0.178\end{array}$ & $\begin{array}{l}4,344 \\
0.097\end{array}$ & $\begin{array}{l}3,258 \\
0.116\end{array}$ & $\begin{array}{l}1,021 \\
0.362\end{array}$ \\
\hline
\end{tabular}

Notes: This table documents marginal effects from a probit model of migration decisions. Education level is categorized into three groups: elementary and lower ( 6 years of school and below); junior middle school ( 9 years of school); senior middle school and higher (at least 12 years of school). The reference educational group is elementary and lower. Note that the obligatory/subsidized educational level imposed by the Chinese government is junior middle school. Household income is the highest level of monthly income among all household members, in thousands of Yuan in 2009. Note that the estimated standard errors are robust, and ***,**, and *, respectively, refer to significance at the $1 \%, 5 \%$ and $10 \%$ level (two-sided test). Veall and Zimmermann (1992) discuss Pseudo- ${ }^{2}$ measures for probit models.

Source: 2009 Rural Household Survey of RUMiC. 


\begin{tabular}{lccc}
\hline & Mean & St.Dev & N \\
\hline Expropriated & 2.68 & 2.31 & 324 \\
Movers & & & \\
Highly skilled & 3.72 & 2.4 & 229 \\
Migrant from close by & 3.71 & 2.55 & 454 \\
Migrant from far away & 3.60 & 2.62 & 1,775 \\
Stayers & & & \\
Urban stayers & 2.83 & 2.45 & 2,773 \\
Rural stayers & 2.66 & 2.39 & 2,181 \\
\hline
\end{tabular}

Note: Data refer to the year 2009.

Source: Data are extracted from the Urban (Urban stayers and Highly skilled), Migrant (Migrants from close by and Migrants from far away), and Rural (Rural stayers) Household Surveys of RUMiC.

Table 4 - Expropriation and risk attitude

\section{Dependent variable}

Risk attitude

Household head

Spouse

Movers

(a) Highly skilled

(b) Nearby migrants

(c)Far away migrants

$-.28$

(.23)
$-.70$

(.33)

\section{Stayers}
(d) Urban stayers
(e) Rural stayers

Notes: Data refer to the year 2009. Each coefficient is derived from separate regressions on each type of expropriated reference group and household member, in which the dependent variable is the level of risk tolerance and the explanatory variables include demographic characteristics (gender, age, age squared, the interaction between age and age squared and whether expropriated, whether married, height, weight, and the number of children), human capital and employment characteristics (years of education, monthly income), a dummy variable for the expropriated with change in hukou status, and provincial fixed effects. Robust standard errors are in parentheses. Number of observations as follows: Household head: (a): 1753; (b): 301; (c): 496; (d): 1611; (e): 1441. Spouse: (a): 1220; (b): 211; (c): 249; (d): 454; (e): 768 . The symbol *** indicates statistically significantly different from zero at the $1 \%$ level (two-sided test).

Source: Data are extracted from the 2009 Urban, Migrant, and Rural Household RUMiC samples. 
Table 5 - Risk attitude across generations

\begin{tabular}{lcc}
\hline & \multicolumn{2}{c}{ Child migration status } \\
\cline { 2 - 3 } & Mover & Stayer \\
\hline Mean risk tolerance of parents & 1.78 & 1.54 \\
$\mathrm{~N}$ & $(2.13)$ & $(1.97)$ \\
& 120 & 518 \\
\hline
\end{tabular}

Notes: subjective questions in RUMiC are asked only to household members who are present at the interview. The means displayed above refer to such families where members from at least two generations were present at the interview. Standard deviations are given in parentheses.

Source: 2009 Rural Household Survey of RUMiC. 
Table 6 - Risk attitude between children and parents

\begin{tabular}{lcc}
\hline $\begin{array}{l}\text { Dependent variable } \\
\text { risk attitude }\end{array}$ & $\begin{array}{c}\text { Risk attitude } \\
\text { household head }\end{array}$ & $\begin{array}{c}\text { Risk attitud } \\
\text { children }\end{array}$ \\
\hline Parental risk attitude & $0.607^{* * *}$ & $0.446^{* * *}$ \\
& $(0.118)$ & $(0.080)$ \\
Par spousal risk attitude & & $0.336^{* * *}$ \\
& & $(0.085)$ \\
Male & 0.837 & $0.967^{* * *}$ \\
& $(0.943)$ & $(0.331)$ \\
Age & & $0.271^{*}$ \\
& 0.016 & $(0.160)$ \\
Age & & \\
& $(0.232)$ & -0.004 \\
& & $(0.002)$ \\
Junior middle school and below & -0.000 & 0.283 \\
Senior middle school and higher & $(0.003)$ & $(0.437)$ \\
& & 0.330 \\
& -0.254 & $(0.477)$
\end{tabular}

No. of children

$-0.244$

$0.480 * * *$

$(0.390)$

Married

0.331

0.079

$(0.351)$

Monthly income

$0.0004 * * *$

0.000

$(0.0001)$

$(0.000)$

No. siblings

0.038

$-0.183$

$(0.165)$

Height (in cm)

0.004

$-0.027$

(0.049)

Weight (in kg)

$-0.021$

$-0.007$

$(0.025)$

(0.017)

$\begin{array}{lcc}\text { Observations } & 137 & 318 \\ \text { Province } & \text { YES } & \text { YES } \\ \mathrm{R}^{2} & 0.342 & 0.459\end{array}$

Notes: Estimates obtained by OLS with robust standard errors (in parentheses) performed on equation (3). Education level is categorized into three groups: elementary and lower (6 years of school and below); junior middle school (9 years of school); senior middle school and higher (at least 12 years of school). The reference educational group is elementary and lower. Note that the obligatory/subsidized educational level imposed by the Chinese government is junior middle school. Monthly income documents average of monthly income for each individual in Yuan in 2009. Age squared is not divided by $100 . * * *$, and *, respectively, refer to significance at the $1 \%$ and $10 \%$ level (two-sided test). Source: 2009 Rural Household Survey of RUMiC. 


\section{Appendix}

Table A1 - Means of observed variables in samples with complete and incomplete information on risk tolerance

\begin{tabular}{|c|c|c|}
\hline & $\begin{array}{c}\text { Households with } \\
\text { complete information }\end{array}$ & $\begin{array}{c}\text { Households with } \\
\text { incomplete information }\end{array}$ \\
\hline \multicolumn{3}{|l|}{ Demographics } \\
\hline Male (\%) & 63.5 & 68.7 \\
\hline Age & 43.75 & 45.25 \\
\hline $\mathrm{Age}^{2} / 100$ & 19.97 & 21.48 \\
\hline \multicolumn{3}{|c|}{ Family characteristics } \\
\hline No. children & 1.44 & 1.80 \\
\hline Married (\%) & 94.0 & 98.0 \\
\hline No. siblings & 3.0 & 3.3 \\
\hline Height (in cm) & 165.6 & 166.0 \\
\hline Weight (in kg) & 62.5 & 62.9 \\
\hline \multicolumn{3}{|l|}{$\begin{array}{l}\text { Human capital and } \\
\text { labor market }\end{array}$} \\
\hline Years of education & 3.1 & 3.0 \\
\hline $\begin{array}{l}\text { Monthly income } \\
\text { (Yuan) }\end{array}$ & $1,501.0$ & $1,472.0$ \\
\hline \multicolumn{3}{|c|}{$\begin{array}{l}\text { Province of residence } \\
\text { (\%) }\end{array}$} \\
\hline Jiangsu & 14.8 & 16.4 \\
\hline Zhejiang & 29.1 & 23.5 \\
\hline Anhui & 4.5 & 9.9 \\
\hline Henan & 1.6 & 10.0 \\
\hline Hubei & 7.8 & 6.7 \\
\hline Guangdong & 7.4 & 10.4 \\
\hline Chongqing & 1.6 & 2.2 \\
\hline Sichuan & 32.0 & 16.7 \\
\hline
\end{tabular}

Source: Authors' own calculations based on 2009 Rural Household Survey of RUMiC. 
Table A2 - Risk and migration of household head (marginal effects)

\begin{tabular}{|c|c|c|c|c|c|}
\hline Decision to move & I & II & III & IV & $\mathbf{V}$ \\
\hline Risk attitude & $\begin{array}{c}0.018 * * * \\
(0.002)\end{array}$ & $\begin{array}{c}0.011 * * * \\
(0.003)\end{array}$ & $\begin{array}{c}0.011^{* * *} \\
(0.03)\end{array}$ & $\begin{array}{l}0.011^{* * *} \\
(0.003)\end{array}$ & $\begin{array}{c}0.009 * * * \\
(0.003)\end{array}$ \\
\hline Male & & $\begin{array}{c}0.121 * * * \\
(0.019)\end{array}$ & $\begin{array}{c}0.124 * * * \\
(0.020)\end{array}$ & $\begin{array}{c}0.123^{* * *} \\
(0.020)\end{array}$ & $\begin{array}{c}0.127 * * * \\
(0.019)\end{array}$ \\
\hline Age & & $\begin{array}{l}-0.004 \\
(0.006)\end{array}$ & $\begin{array}{l}-0.004 \\
(0.006)\end{array}$ & $\begin{array}{l}-0.004 \\
(0.006)\end{array}$ & $\begin{array}{l}-0.002 \\
(0.007)\end{array}$ \\
\hline $\mathrm{Age}^{2} / 100$ & & $\begin{array}{l}-0.000 \\
(0.000)\end{array}$ & $\begin{array}{l}-0.000 \\
(0.000)\end{array}$ & $\begin{array}{l}-0.006 \\
(0.006)\end{array}$ & $\begin{array}{l}-0.009 \\
(0.006)\end{array}$ \\
\hline Junior middle school & & $\begin{array}{c}0.004 \\
(0.015)\end{array}$ & $\begin{array}{c}0.005 \\
(0.015)\end{array}$ & $\begin{array}{c}0.006 \\
(0.015)\end{array}$ & $\begin{array}{c}0.009 \\
(0.015)\end{array}$ \\
\hline Senior middle school + & & $\begin{array}{l}-0.031^{*} \\
(0.018)\end{array}$ & $\begin{array}{c}-0.030^{*} \\
(0.018)\end{array}$ & $\begin{array}{l}-0.029 \\
(0.018)\end{array}$ & $\begin{array}{l}-0.0234 \\
(0.019)\end{array}$ \\
\hline No. of children & & & $\begin{array}{l}-0.011 \\
(0.007)\end{array}$ & $\begin{array}{l}-0.012 * \\
(0.007)\end{array}$ & $\begin{array}{l}-0.010 \\
(0.008)\end{array}$ \\
\hline Marital status & & & $\begin{array}{c}0.021 \\
(0.035)\end{array}$ & $\begin{array}{c}0.024 \\
(0.033)\end{array}$ & $\begin{array}{c}0.032 \\
(0.035)\end{array}$ \\
\hline Household size & & & & $\begin{array}{l}-0.000 \\
(0.006)\end{array}$ & $\begin{array}{l}-0.001 \\
(0.006)\end{array}$ \\
\hline Land size & & & & $\begin{array}{c}0.000 \\
(0.001)\end{array}$ & $\begin{array}{l}-0.001 \\
(0.002)\end{array}$ \\
\hline No. siblings & & & $\begin{array}{c}0.002 \\
(0.003)\end{array}$ & $\begin{array}{c}0.002 \\
(0.003)\end{array}$ & $\begin{array}{c}0.005 \\
(0.003)\end{array}$ \\
\hline Height (in $\mathrm{cm}$ ) & & & $\begin{array}{l}-0.000 \\
(0.001)\end{array}$ & $\begin{array}{l}-0.000 \\
(0.001)\end{array}$ & $\begin{array}{c}0.000 \\
(0.001)\end{array}$ \\
\hline Weight (in kg) & & & $\begin{array}{l}-0.000 \\
(0.001)\end{array}$ & $\begin{array}{l}-0.000 \\
(0.001)\end{array}$ & $\begin{array}{c}0.000 \\
(0.001)\end{array}$ \\
\hline Household mean age & & & & $\begin{array}{l}-0.000 \\
(0.001)\end{array}$ & $\begin{array}{c}0.000 \\
(0.001)\end{array}$ \\
\hline Household income & & & & $\begin{array}{l}-0.001 \\
(0.003)\end{array}$ & $\begin{array}{c}0.002 \\
(0.003)\end{array}$ \\
\hline Province FE & NO & $\mathrm{NO}$ & $\mathrm{NO}$ & $\mathrm{NO}$ & YES \\
\hline $\begin{array}{l}\text { Observations: } 4,344 \\
\text { McFadden's Pseudo R }\end{array}$ & 0.0106 & 0.0775 & 0.0785 & 0.0786 & 0.0970 \\
\hline
\end{tabular}

Notes: This table documents marginal effects from a probit model of migration decisions increasingly adding control terms. Education level is categorized into three groups: elementary and lower ( 6 years of school and below); junior middle school ( 9 years of school); senior middle school and higher (at least 12 years of school). The reference educational group is elementary and lower. Note that the obligatory/subsidized educational level imposed by the Chinese government is junior middle school. Household income is the highest level of monthly income among all household members, in thousands of Yuan in 2009. Note that the estimated standard errors are robust, and ***, **, and *, respectively, refer to significance at the $1 \%, 5 \%$ and $10 \%$ level (two-sided test). Veall and Zimmermann (1992) discuss Pseudo- $\mathrm{R}^{2}$ measures for probit models.

Source: 2009 Rural Household Survey of RUMiC. 


\section{References}

Akgüç, Mehtap, Corrado Giulietti, and Klaus F. Zimmermann. 2014a. The RUMiC Longitudinal Survey: Fostering Research on Labor Markets in China. IZA Journal of Labor \& Development 3:5.

Akgüç, Mehtap, Xingfei Liu, and Massimiliano Tani. 2014b. Expropriation with Hukou Change: Evidence from a Quasi-Natural Experiment. Working Paper No. 8689, IZA, Bonn, Germany.

Arrow, Kenneth. 1965. Aspects of the Theory of Risk-Bearing. Helsinki, Yrjš Jahnsson Foundation.

Bonin, Holger, Amelie F. Constant, Konstantinos Tatsiramos, and Klaus F. Zimmermann. 2009. Native-Migrant Differences in Risk Attitudes. Applied Economics Letters 16: 1581-1586.

Bonin, Holger, Amelie F. Constant, Konstantinos Tatsiramos, and Klaus F. Zimmermann. 2012. Ethnic Persistence, Assimilation and Risk Proclivity. IZA Journal of Migration $1: 5$

Borjas, George J. 1987. Self-selection and the Earnings of Immigrants. American Economic Review 77: 531-553.

Borjas, George J. 2001. Does Immigration Grease the Wheels of the Labor Market? Brookings Papers on Economic Activity 1: 69-133.

Brown, Heather, and Marjon van der Pol. 2015. Intergenerational Transfer of Time and Risk Preferences. Journal of Economic Psychology 49: 187-204.

Case, Anne, and Christina Paxson. 2008. Stature and Status: Height, Ability, and Labor Market Outcomes. Journal of Political Economy 116(3): 499-532.

Chan, Kam Wing. 2009. The Chinese Hukou System at 50. Eurasian Geography and Economics 50(2):197-221.

Chen, Kong-Pin, Shin-Hwan Chiang, and Siu Fai Leung. 2003. Migration, Family, and Risk Diversification. Journal of Labor Economics 21: 353-380.

Conroy, Hector V. 2009. Risk Aversion, Income Variability, and Migration in Rural Mexico. California Center for Population Research, UCLA, working draft.

Czaika, Mathias. 2012. Migrations in Times of Uncertainty: On the Role of Economic Prospects. DEMIG Project Paper No. 11, International Migration Institute, University of Oxford.

Dohmen, Thomas, Armin Falk, David Huffman, Uwe Sunde, Jürgen Schupp, and Gert G. Wagner. 2011. Individual Risk Attitudes: Measurement, Determinants, and Behavioral Consequences. Journal of the European Economic Association 9: 522-550. 
Dohmen, Thomas, Armin Falk, David Huffman, and Uwe Sunde. 2012. The Intergenerational Transmission of Risk and Trust Attitudes. The Review of Economic Studies 79: 645677.

Dohmen, Thomas, Hartmut Lehmann, and Norberto Pignatti. 2015. Risk Attitudes and Labor Market Outcomes over the Great Recession: A Comparison of Ukraine and Germany. Paper presented at the 10th IZA-World Bank conference on Employment and Development, Bonn, Germany 4-6 June.

Dustmann, Christian. 1997. Return Migration, Uncertainty and Precautionary Savings. Journal of Development Economics 52: 295-316.

Dustmann, Christian, Fasani, Francesco, Meng, Xin, and Luigi Minale. 2015. Risk Attitudes and Household Migration Decisions. University College London: unpublished mimeo.

Frijters, Paul, Kong, Tao and Meng, Xin. 2011. Migrant Entrepreneurs and Credit Constraints under Labour Market Discrimination. IZA Discussion Papers 5967.

Gibson, John and David McKenzie. 2009. The Microeconomic Determinants of Emigration and Return Migration of the Best and Brightest: Evidence from the Pacific. Journal of Development Economics 95(1): 18-29.

Guiso, Luigi, and Monica Paiella, 2006. The Role of Risk Aversion in Predicting Individual Behavior. In Pierre-André Chiappori and Christian Gollier (Eds.), Insurance: Theoretical Analysis and Policy Implications. MIT Press: Cambridge.

Heitmueller, Axel. 2005. Unemployment Benefits, Risk Aversion, and Migration Incentives. Journal of Population Economics 18: 93-112.

Hao, Li, Daniel Houser, Lei Mao, and Marie Claire Villeval. 2014. A Field Study of Chinese Migrant Workers' Attitudes toward Risks, Strategic Uncertainty, and Competitiveness. Working Paper No. 8227, IZA, Bonn, Germany.

Harris, John R., and Michael P. Todaro. 1970. Migration, Unemployment and Development: A Two-Sector Analysis. The American Economic Review 60: 126-142.

Jaeger, David A., Thomas Dohmen, Armin Falk, David Huffman, Uwe Sunde, and Holger Bonin. 2010. Direct Evidence on the Risk Attitudes and Migration. The Review of Economics and Statistics 92: 684-689.

Jalan, Jyotsna, and Martin Ravallion. 2001. Behavioral Responses to Risk in Rural China. Journal of Development Economics 66: 23-49.

Katz, Eliakim, and Oded Stark. 1986. Labor Migration and Risk Aversion in Less Developed Countries. Journal of Labor Economics 4: 134-149.

Kimball, Miles S., Claudia R. Sahm, and Matthew D. Shapiro. 2009. Risk Preferences in the PSID: Individual Imputations and Family Covariation. American Economic Review: Papers \& Proceedings 99: 363-368.

Lehmann, Hartmut, Alexander Muravyev, and Klaus F. Zimmermann. 2012. The Ukrainian Longitudinal Monitoring Survey: Towards a Better Understanding of Labor Markets in Transition. IZA Journal of Labor \& Development 1, Article 9. 
Meng, Xin, Chris Manning, Shi Li, and Tadjuddin Noer Effendi. 2010. The Great Migration Rural-Urban Migration in China and Indonesia. Edward Elgar Publishing, Inc. William Pratt House, USA.

Pratt, John. 1964. Risk Aversion in the Small and in the Large. Econometrica 32: 122-136.

Rosenzweig, Mark R. 1988. Risk, Implicit Contracts and the Family in Rural Areas of LowIncome Countries. The Economic Journal 98: 1148-1170.

Rosenzweig, Mark R., and Oded Stark. 1989. Consumption Smoothing, Migration, and Marriage: Evidence from Rural India. Journal of Political Economy 97: 905-926.

Sahota, Gian S. 1968. An Economic Analysis of Internal Migration in Brazil. The Journal of Political Economy: 218-245.

Sicular, Terry, Yue Ximing, Björn Gustafsson, and Shi Li. 2007. The Urban-Rural Income Gap and Inequality in China. Review of Income and Wealth 53: 93-126.

Simon, Herbert A. 1983. Reason in Human Affairs. Stanford, Calif.: Stanford University Press.

Sjaastad, Larry A. 1962. The Costs and Returns of Human Migration. Journal of Political Economy 70: 80-93.

Stark, Oded. 1981. On the Optimal Choice of Capital Intensity in LDCs with Migration. Journal of Development Economics 9: 31-41.

Stark, Oded. 1991. The Migration of Labor. Cambridge, MA: Basil Blackwell.

Stark, Oded, and David Levhari. 1982. On Migration and Risk in LDCs. Economic Development and Cultural Change 31: 191-196.

Stark, Oded, and Robert E.B. Lucas. 1988. Migration, Remittances, and the Family. Economic Development and Cultural Change 36: 465-481.

Todaro, Michael P. 1969. A Model of Labor Migration and Urban Unemployment in Less Developed Countries. The American Economic Review 59: 138-148.

Veall, Michael R., and Klaus F. Zimmermann. 1992. Pseudo-R 2's in the Ordinal Probit Model. Journal of Mathematical Sociology 16 (4), 333-342.

Williams, Allan M., and Vladimir Baláž. 2014. Mobility, Risk Tolerance and Competence to Manage Risks. Journal of Risk Research 17: 1061-1088.

Zhao, Zhong. 2005. Migration, Labor Market Flexibility, and Wage Determination in China: A Review. The Developing Economies 43: 285-312. 